\title{
Genomics in the UK: Mapping the Social Science Landscape
}

\author{
MICHAEL BANNER \& JONATHAN E. SUK
}

\begin{abstract}
This paper has been prepared from the perspective of the ESRC Genomics Policy \& Research Forum, which has the particular mandate of linking social science research on genomics with ongoing public and policy debates. It is intended as a contribution to discussions about the future agenda for social scientific analyses of genomics. Given its scope, this paper is necessarily painted with a broad brush. It is presented in the hope that it can serve both as a useful reference for those less familiar with the themes and foci of UK-based social science research about genomics and, for those more engaged in the field, as a foundation for discussions about the future social sciences agenda in this area. This paper has four parts. The first identifies the boundaries of the topic. It is suggested that the boundaries of genomics are properly regarded by social scientists as soft rather than hard, and as encompassing far more than genomics as narrowly understood. In the second part, the UK context for social science research is briefly described before proceeding to part three, which offers a survey of the major areas and patterns of research. This is organised by reference to the themes of globalisation, governance and regulation, and refers to 129 current or recently completed projects (surveyed during the winter of 2005) that address these themes. Part four proposes some appropriate areas for future research, drawing on and advancing what has been achieved thus far. Social scientific analyses of the nature and consequences of genomic science, it is claimed, have been crucially framed by the institutionalising of non-scientific considerations under the heading of ELSA/ELSI (Ethical, Legal and Social Aspects/Implications). It is suggested that an understanding of the limitations and consequences of this framing provides a vital starting point in considering future research agendas.
\end{abstract}

\section{Part I - The Boundaries of Genomics}

Whilst the much-celebrated completion of the sequencing of the human genome has given a certain familiarity in popular discourse to the word 'genome' (taken as signifying something to be understood as a sort of map or code of our genetic material), the word 'genomics' has gained much less currency and still less any depth of understanding. But even where there is a recognition of the term, there is often an uncertainty about its meaning and use. It was the experience of the Genomics Forum, in inviting a wide range of interested participants to meetings to discuss issues in human, animal and plant genomics, that even (perhaps especially) amongst interested parties, the use of the term 'genomics' is problematic.

Natural scientists understood the term, reasonably enough, to refer to a set of techniques or technologies specifically to do with the mapping or sequencing of genomes. In addition they associated genomics with 'post-genomic' disciplines (such as proteomics or metabolomics) and with developments of the quantitative and computational tools needed to exploit the vast amounts of data generated by sequencing technologies. Participants with different backgrounds and with different 
interests (including policy-makers, members of civil society organisations, and social scientists) tended to use the term 'genomics' more loosely to signify something that might be called 'genetic technologies'. In this latter usage, 'genomics' was not sharply distinguished from, for example, genetically modified (GM) crops, genetic modification more broadly, gene therapy, genetic testing, cloning, xenotransplantation and even the use of stem cells. On occasions - and particularly, it seemed, where there was a fear that the controversy surrounding GM might somehow become attached to genomics unless the distinction were maintainednatural scientists found it necessary to try and maintain the more limited usage of the term 'genomics' and to complain of a risk of confusion. They pointed out, for example, that genomics and genetic modification are two distinct things, in the sense that the mapping and sequencing of genomes proceeds independently of genetic modification, and vice versa; there was plainly genetic modification before there was genomics, and there could be genomics whether or not there is genetic modification. This insistence on difference and discontinuity is, of course, also part of the wider presentation of the development of genomics as constituting a revolution in the biological sciences.

In understanding the scope of the social science of genomics (and thus the concern of this paper) it is important to recognise both the merit of the natural scientists' rather precise usage, but also why the looser use of the term and the regular association of genomics with a range of other technologies points to something important about these scientific developments. The contrast between these two connotations of 'genomics' bears some elaboration.

If the genome is thought of as the totality of genetic material that provides the code which makes us what we are, then genomics is the science of this totality. By means of tools of mapping, sequencing and analysis of genetic material as a totality, genomics seeks an understanding of the functions and interactions of this genetic material and thus an understanding of the biology of organisms.

Understood in this way, the term 'genomics' refers us to the very specific scientific developments which led to and were advanced by the high-profile mapping projects which captured public attention. Even understood in this narrow sense, genomics opens up a rich field for social scientific reflection and analysis. The sequencing of the human genome was a major international programme of research and cooperation which involved huge effort and resources and which commanded considerable financial and political support, as well as significant media and public attention. The processes and institutions which shaped and were shaped by this scientific endeavour are quite properly the subject of investigation, as are the implications of genomics for understandings of what it is to be human, and a human individual.

If this, however, identifies the scope of genomics from a scientific viewpoint, those at the Forum's meetings who understood genomics less precisely, or who immediately associated genomics with a wide range of other biotechnologies, should not simply be disregarded as mistaken. 'Genomics', understood in the narrow sense, is a range of techniques and technologies which enable us better to understand and hence to engage with living organisms. It is, if you like, a tool (or set of tools) which 
increases our power to understand, and hence to affect, shape or manipulate the natural world. Thus, though it should not be confused with biotechnology in general, or genetic modification or stem cell research in particular, the tendency of popular discussions to link these separate activities indicates something of great importance-for the very sense of interest and high excitement around genomics is just that this tool increases the power of the other tools of biotechnology. Thus, though it is undeniable, for example, that there was genetic modification before there was genomics (and that one could pursue genomics while eschewing genetic modification), genomics enables scientists to make genetic modification more efficient and effective (although, arguably, it may also render GM otiose). Genomics is not genetic modification, but the linking of the two is not straightforwardly wrong. A hammer is not a chisel, and there may have been hammers before there were chisels, or vice versa; but the social significance of these two tools could hardly be comprehended were their study to be sharply differentiated.

When this is understood, it can be seen that the proper scope of the study of genomics for social science is much wider (and less easily bounded) than would be the study of genomics as understood by many natural scientists as an important but discrete field of contemporary science. Genomics is a tool, which has arisen from the advances in biology and genetics that span the fifty years from the discovery of the structure of DNA in 1953 to the sequencing of the human genome in 2003. It is a part of this story and intimately connected with the other elements of it, conceptually, practically and in popular thought and discourse. It is related to, and has implications for, all those things which are often connected with it, such as GM crops, genetic modification more broadly, gene therapy, genetic testing, cloning, xeno-transplantation, the use of stem cells and so on. Social science will be concerned to understand what is significant and important about genomic science narrowly construed; but it would be guilty of ignoring the wider context of meaning and significance in which genomics has been developed and which it has the power to affect and transform, if it concerned itself with the field as narrowly identified for the purpose of demarcating the specialisms of contemporary biology.

\section{Part II - The UK Context}

A substantial amount of time, money and energy has been invested in the UK in social scientific research relating to genomics. This has been co-ordinated principally through Universities, associated think-tanks, and a wide range of funding bodies. The Economic and Social Research Council (ESRC) is a core UK funder of social scientific research and has sponsored a wide range of genomics-related activities. This commitment has been reviewed elsewhere. ${ }^{1}$ For the purposes of this paper, most relevant is the ESRC Genomics Network (EGN), a $£ 12.5$ million investment which comprises the research centres Cesagen (Universities of Cardiff and Lancaster), Egenis (University of Exeter), and Innogen (University of Edinburgh and the Open University), as well as the ESRC Genomics Policy and Research Forum and ESRC Attitudes to Genomics Survey. The ESRC has also sponsored two research programmes, Science in Society and Innovative Health Technologies, which in turn have funded many projects relevant to analyses of genomics in society. ${ }^{2}$ Other funding bodies which have invested heavily in research on genomics and society include the Wellcome Trust, the Leverhulme Trust and the European Commission. ${ }^{3}$ 
In addition to the centres of the EGN, several UK research institutes have run or are running programmes related to genomics and society. These include the Science and Technology Studies Unit (SATSU) at the University of York; The Institute for the Study of Genetics, Biorisks and Society (IGBiS) at the University of Nottingham; The Policy, Ethics and Life Sciences Research Centre (PEALS), a partnership between the Universities of Durham and Newcastle and the Centre for Life; The BIOS Centre of the London School of Economics; and the Science \& Technology Research Unit (SPRU) at the University of Sussex. Further, the Nuffield Council on Bioethics, the Oxford Centre for Ethics and Communication in Health Care Practice (Ethox), sponsored by the Ethox foundation, and the University of Cambridge Centre for Medical Genetics and Policy (CMGP), associated with the Cambridge Genetics Knowledge Park, conduct research relevant to genomics and society.

Thus the UK is host to a wide range of research centres, funding bodies, and academic units focussed on the social and policy aspects of genomics research. Collectively, these centres have conducted an extensive amount of research seeking to understand how, and whether, the advent of genomics and post-genomics research is fundamentally altering society. The following section seeks to draw upon as much of this research as possible whilst remaining coherent and concise.

\section{Part III - Genomics and Social Science: A Survey of Current Research in Genomics in the UK}

Our current epoch is often characterised as one of radical and transformative change in which boundaries - between state and society, global and local, even between the natural and unnatural-become increasingly blurred. Genomics has been developed and will continue to develop in this context of change, and will itself be shaped by, and contribute to, further transformations.

This section summarises some of the recent UK-based research that has devoted itself to elucidating and understanding such transformations. It is organised with reference to three broad themes: globalisation, development and genomics; governance, publics and genomics; and regulation, innovation and genomics. These themes were selected after the research projects reviewed for this paper (see Table 1 below ${ }^{4}$ ) were analysed according to their empirical and theoretical focus and principle research questions. The desire was to classify the projects with reference to a limited number of themes in order to appropriately represent individual projects whilst also encompassing the vast array of research surveyed in this paper. Thus the classification of projects according to the aforementioned themes is best viewed of as 'fluid': the themes provide a context for, and means of organising, this survey of current UK-based social science research engaging genomics and the broader range of biotechnologies from which it has arisen and with which it is associated. ${ }^{5}$ 
Table 1. Ongoing and Recently Completed UK Research in the Social Science of Genomics

\begin{tabular}{|c|c|c|c|}
\hline Project & Institute & Project & Project Leader(s) \\
\hline 1 & University of Dundee & $\begin{array}{l}\text { A new geography of health: transforming } \\
\text { heart disease in the new genetics era }\end{array}$ & E.C. Hall, \\
\hline 2 & $\begin{array}{l}\text { Wellcome Trust- } \\
\text { KEMRI, Research } \\
\text { Programme, Kenya }\end{array}$ & $\begin{array}{l}\text { Action research to develop IEC materials } \\
\text { that support informed consent processes } \\
\text { for research in developing countries. }\end{array}$ & $\begin{array}{l}\text { Catherine S. } \\
\text { Molyneux }\end{array}$ \\
\hline 3 & Cesagen & Indigenous Peoples & Brian Wynne \\
\hline 4 & Innogen & $\begin{array}{l}\text { Genomic and biotechnology partnerships } \\
\text { in Africa }\end{array}$ & Joanna Chataway \\
\hline 5 & Innogen & $\begin{array}{l}\text { Genomics and biotechnology partnerships } \\
\text { in less developed countries }\end{array}$ & Joanna Chataway \\
\hline 6 & Innogen & $\begin{array}{l}\text { Institutional Impacts of North-South } \\
\text { partnerships in agricultural biotechnology }\end{array}$ & Jane Bower \\
\hline 7 & $\begin{array}{l}\text { Cesagen (In part of } \\
\text { collaboration) }\end{array}$ & $\begin{array}{l}\text { Genomics and Benefit Sharing with } \\
\text { Developing Countries (BeSha) }\end{array}$ & Ruth Chadwick \\
\hline 8 & $\begin{array}{l}\text { Cesagen (In part of } \\
\text { collaboration with } \\
\text { Centre for Science, } \\
\text { Society and } \\
\text { Citizenship in Rome) }\end{array}$ & $\begin{array}{l}\text { Bioethical Implications of Globalisation } \\
\text { Processes (BIG) }\end{array}$ & Ruth Chadwick \\
\hline 9 & Egenis & $\begin{array}{l}\text { The impact of advanced genomics-based } \\
\text { tools for agronomy, plant breeding and } \\
\text { food production on local agricultural } \\
\text { practices }\end{array}$ & Steve Hughes \\
\hline 10 & $\begin{array}{l}\text { University of East } \\
\text { Anglia }\end{array}$ & $\begin{array}{l}\text { The global politics of human embryonic } \\
\text { stem cell regulation }\end{array}$ & Brian Salter \\
\hline 11 & $\begin{array}{l}\text { SPRU, University of } \\
\text { Sussex }\end{array}$ & $\begin{array}{l}\text { Report production on the latest trends of } \\
\text { Life Science and Biotechnology in Europe }\end{array}$ & $\begin{array}{l}\text { Nick von } \\
\text { Tunzelmann }\end{array}$ \\
\hline 12 & $\begin{array}{l}\text { University of } \\
\text { Cambridge: Centre } \\
\text { for Business Research }\end{array}$ & $\begin{array}{l}\text { Corporate responses to macroeconomic } \\
\text { changes and shocks }\end{array}$ & M. Kitson \\
\hline 13 & $\begin{array}{l}\text { Cardiff University, } \\
\text { Watt University, } \\
\text { University of Wales } \\
\text { College of Medicine }\end{array}$ & $\begin{array}{l}\text { Genetic testing and insurance: the } \\
\text { problem of adverse selection }\end{array}$ & Lindsay Prior \\
\hline 14 & Cesagen & The economics of innovation in genomics & Phil Cooke \\
\hline 15 & University of Leeds & $\begin{array}{l}\text { Social And Ethnic Differences In } \\
\text { Attitudes And Consent To Prenatal } \\
\text { Testing }\end{array}$ & Jenny Hewison \\
\hline 16 & $\begin{array}{l}\text { University of } \\
\text { Cambridge }\end{array}$ & Informed consent and genetic data & Dr Onora O'Neill \\
\hline 17 & $\begin{array}{l}\text { School of Nursing \& } \\
\text { Midwifery, King's } \\
\text { College London }\end{array}$ & $\begin{array}{l}\text { Facilitating choice, framing choice: the } \\
\text { experience of staff working in } \\
\text { preimplantation genetic diagnosis. }\end{array}$ & Clare Williams \\
\hline 18 & IGBiS (Nottingham) & $\begin{array}{l}\text { Genetic Counselling for } \\
\text { Haemochromatosis }\end{array}$ & Melanie Pearce \\
\hline 19 & $\begin{array}{l}\text { Genetic Interest } \\
\text { Group and University } \\
\text { of Southampton }\end{array}$ & The Human Rights Act and genetics & Mr John Gillott \\
\hline
\end{tabular}




\begin{tabular}{|c|c|c|c|}
\hline Project & Institute & Project & Project Leader(s) \\
\hline 20 & University of Bristol & $\begin{array}{l}\text { Ethical protection in epidemiological } \\
\text { genetic research: participants' perspectives }\end{array}$ & Alastair Campbell \\
\hline 21 & BIOS (LSE) & $\begin{array}{l}\text { Genome-based Therapeutic Drugs for } \\
\text { Depression (GENDEP) }\end{array}$ & Ilina Singh \\
\hline 22 & $\begin{array}{l}\text { London Metropolitan } \\
\text { University, } \\
\text { University of } \\
\text { Birmingham, } \\
\text { Imperial College, } \\
\text { University of London }\end{array}$ & $\begin{array}{l}\text { Ethical issues in the collection of } \\
\text { pregnancy-related tissue samples }\end{array}$ & $\begin{array}{l}\text { Naomi Pfeffer, } \\
\text { Donna Dickenson }\end{array}$ \\
\hline 23 & IGBiS (Nottingham) & $\begin{array}{l}\text { Mothers' Responses to the Possibility of } \\
\text { Pre-Implantation Genetic Modification of } \\
\text { their Babies }\end{array}$ & Susan Johnson \\
\hline 24 & $\begin{array}{l}\text { Centre for Ethics in } \\
\text { Medicine, University } \\
\text { of Bristol; Institute of } \\
\text { Ethics and Law in } \\
\text { Medicine, University } \\
\text { of Glasgow }\end{array}$ & $\begin{array}{l}\text { Scoping Study: Ethical and practical } \\
\text { concerns in changes to human tissue } \\
\text { legislation. }\end{array}$ & $\begin{array}{l}\text { Alastair Campbell } \\
\text { and Sheila } \\
\text { McLean }\end{array}$ \\
\hline 25 & $\begin{array}{l}\text { King's College, } \\
\text { University of London }\end{array}$ & $\begin{array}{l}\text { Informed consent in Sri Lanka: Current } \\
\text { practices, quality of the information } \\
\text { leaflets, consent forms and participants } \\
\text { understanding process }\end{array}$ & $\begin{array}{l}\text { Athula } \\
\text { Sumathipala }\end{array}$ \\
\hline 26 & $\begin{array}{l}\text { Institute of Law \& } \\
\text { Ethics in Medicine, } \\
\text { University of } \\
\text { Glasgow }\end{array}$ & Ethico-legal governance in healthcare. & Sheila Mclean \\
\hline 27 & $\begin{array}{l}\text { University of } \\
\text { Cambridge }\end{array}$ & $\begin{array}{l}\text { From the corporeal to the informational: } \\
\text { recent transformations in the constitution } \\
\text { of collections of human biological } \\
\text { materials and their implications for access } \\
\text { and use }\end{array}$ & Bronwyn Parry \\
\hline 28 & PEALS & $\begin{array}{l}\text { Ordinary Ethics: moral evaluation of the } \\
\text { new genetics by non-professionals }\end{array}$ & Tom Shakespeare \\
\hline 29 & $\begin{array}{l}\text { Cesagen (co- } \\
\text { ordinating institution) }\end{array}$ & $\begin{array}{l}\text { The Institutionalisation of Ethics in } \\
\text { Science Policy: Practices and Impact } \\
\text { (INES) }\end{array}$ & Ruth Chadwick \\
\hline 30 & $\begin{array}{l}\text { Department of } \\
\text { Sociology, University } \\
\text { of Exeter }\end{array}$ & $\begin{array}{l}\text { Accountability and the governance of } \\
\text { expertise: anticipating genetic bioweapons }\end{array}$ & Brian Rappert \\
\hline 31 & $\begin{array}{l}\text { Mountbatten Centre } \\
\text { for International } \\
\text { Studies, University of } \\
\text { Southampton } \\
\end{array}$ & $\begin{array}{l}\text { Science, Security and Regulation: How } \\
\text { effective are export controls? }\end{array}$ & Jez Littlewood \\
\hline 32 & $\begin{array}{l}\text { SPRU, University of } \\
\text { Sussex }\end{array}$ & Dual use controls and genomic research & Paul Nightingale \\
\hline 33 & IGBiS (Nottingham) & $\begin{array}{l}\text { Representations of Complexity in Policy } \\
\text { Networks }\end{array}$ & Ian Forbes \\
\hline 34 & $\begin{array}{l}\text { University of } \\
\text { Leicester }\end{array}$ & $\begin{array}{l}\text { Childhood cancer tissue donations: A gift } \\
\text { relationship? }\end{array}$ & $\begin{array}{l}\text { Mary Dixon- } \\
\text { Woods }\end{array}$ \\
\hline
\end{tabular}




\begin{tabular}{|c|c|c|c|}
\hline Project & Institute & Project & Project Leader(s) \\
\hline 35 & $\begin{array}{l}\text { Innogen (University } \\
\text { of Edinburgh) }\end{array}$ & $\begin{array}{l}\text { Legal and bioethical regulatory } \\
\text { mechanisms }\end{array}$ & Graeme Laurie \\
\hline 36 & Cesagen & Genetic Databases & Ruth Chadwick \\
\hline 37 & $\begin{array}{l}\text { Dept of Sociology \& } \\
\text { Social Policy, } \\
\text { University of Durham }\end{array}$ & $\begin{array}{l}\text { Forensic DNA databasing: A European } \\
\text { perspective }\end{array}$ & Robin Williams \\
\hline 38 & $\begin{array}{l}\text { University of } \\
\text { Cambridge and } \\
\text { Anglia Polytechnic } \\
\text { University }\end{array}$ & $\begin{array}{l}\text { Policy issues in the evaluation of clinical } \\
\text { genetic testing }\end{array}$ & $\begin{array}{l}\text { David Melzer, Ron } \\
\text { Zimmern, Simon } \\
\text { Sanderson }\end{array}$ \\
\hline 39 & $\begin{array}{l}\text { University of East } \\
\text { Anglia }\end{array}$ & $\begin{array}{l}\text { Reforming the Governance Of Human } \\
\text { Genetics: The Politics Of Public Trust }\end{array}$ & Brian Salter \\
\hline 40 & $\begin{array}{l}\text { Innogen (University } \\
\text { of Edinburgh) }\end{array}$ & $\begin{array}{l}\text { The national and international policy } \\
\text { environment for genomics }\end{array}$ & Joyce Tait \\
\hline 41 & IGBiS (Nottingham) & The Politics of Food & Brigitte Nerlich \\
\hline 42 & Innogen & $\begin{array}{l}\text { Interests and values in risk-related } \\
\text { stakeholder interactions }\end{array}$ & Joyce Tait \\
\hline 43 & $\begin{array}{l}\text { SATSU, York } \\
\text { University }\end{array}$ & $\begin{array}{l}\text { Quality assured science: the role of } \\
\text { standards in stabilising stem cell research }\end{array}$ & Andrew Webster \\
\hline 44 & $\begin{array}{l}\text { University of Durham } \\
\text { and University of } \\
\text { Nottingham }\end{array}$ & $\begin{array}{l}\text { Genetic information and crime } \\
\text { investigation: social, ethical and public } \\
\text { policy aspects of the establishment, } \\
\text { expansion and police use of the National } \\
\text { DNA Database (NDNAD) }\end{array}$ & $\begin{array}{l}\text { Robin Williams, } \\
\text { Paul Martin }\end{array}$ \\
\hline 45 & $\begin{array}{l}\text { University of } \\
\text { Lancaster (IEPPP) }\end{array}$ & $\begin{array}{l}\text { Participation and the Dynamics of Social } \\
\text { Positioning (PARADYS) }\end{array}$ & $\begin{array}{l}\text { Bronislaw } \\
\text { Szerszynski, } \\
\text { Norman } \\
\text { Fairclough (UK } \\
\text { component of } \\
\text { international } \\
\text { programme) }\end{array}$ \\
\hline 46 & $\begin{array}{l}\text { Innogen (The Open } \\
\text { University) }\end{array}$ & $\begin{array}{l}\text { Trading up environmental standards? } \\
\text { Trans-Atlantic governance of GM crops }\end{array}$ & $\begin{array}{l}\text { D. Wield, Susan } \\
\text { Carr }\end{array}$ \\
\hline 47 & $\begin{array}{l}\text { University of } \\
\text { Birmingham }\end{array}$ & The politics of GM food & David Marsh \\
\hline 48 & $\begin{array}{l}\text { University of } \\
\text { Cambridge }\end{array}$ & Information policy for pharmacogenetics & David Melzer \\
\hline 49 & University of Oxford & Governing genetic databases & Michael Parker \\
\hline 50 & Cardiff University & $\begin{array}{l}\text { The clinical picture: the interaction of } \\
\text { clinical medicine and genetic technology }\end{array}$ & J. Latimer \\
\hline 51 & University of Oxford & $\begin{array}{l}\text { Ideas, experts and the politics of eugenics: } \\
\text { a comparative and historical analysis }\end{array}$ & Desmond King \\
\hline 52 & $\begin{array}{l}\text { University of } \\
\text { Edinburgh / York } \\
\text { University (SATSU) }\end{array}$ & Transformations in Genetic Subjecthood & $\begin{array}{l}\text { Sarah } \\
\text { Cunningham- } \\
\text { Burley, Anne Kerr } \\
\text { (now at University } \\
\text { of Leeds) }\end{array}$ \\
\hline 53 & IGBiS (Nottingham) & $\begin{array}{l}\text { Exploring the implications of using race/ } \\
\text { ethnicity in applied population genetics }\end{array}$ & Paul Martin \\
\hline
\end{tabular}




\begin{tabular}{|c|c|c|c|}
\hline Project & Institute & Project & Project Leader(s) \\
\hline 54 & Cardiff University & $\begin{array}{l}\text { Genetics, religion and identity : a study of } \\
\text { Bangladeshi Muslims in Britain }\end{array}$ & S. Gilliat-Ray \\
\hline 55 & $\begin{array}{l}\text { Queen Mary: } \\
\text { University of London }\end{array}$ & $\begin{array}{l}\text { Genealogy and genetics : cultural } \\
\text { geographies of relatedness }\end{array}$ & Catherine Nash \\
\hline 56 & $\begin{array}{l}\text { SPRU, University of } \\
\text { Sussex }\end{array}$ & $\begin{array}{l}\text { The Patenting of Human DNA: Global } \\
\text { trends in commercial and public sector } \\
\text { activity }\end{array}$ & Sandra Thomas \\
\hline 57 & $\begin{array}{l}\text { University of } \\
\text { Warwick }\end{array}$ & $\begin{array}{l}\text { The evolution of biomedical knowledge: } \\
\text { interactive innovation in the UK and US }\end{array}$ & Jacky Swan \\
\hline 58 & IGBiS (Nottingham) & Genetic Testing & $\begin{array}{l}\text { Robert Frost, Paul } \\
\text { Martin }\end{array}$ \\
\hline 59 & Innogen & $\begin{array}{l}\text { The public and private organisation of } \\
\text { genetic information }\end{array}$ & David Wield \\
\hline 60 & $\begin{array}{l}\text { IGBiS (Nottingham) / } \\
\text { SPRU }\end{array}$ & $\begin{array}{l}\text { The Impact of Genomics on Innovation in } \\
\text { the Pharmaceutical Industry }\end{array}$ & $\begin{array}{l}\text { Paul Martin, Paul } \\
\text { Nightingale }\end{array}$ \\
\hline 61 & $\begin{array}{l}\text { University of } \\
\text { Cambridge: Centre } \\
\text { for Business Research }\end{array}$ & $\begin{array}{l}\text { Commercializing science : entrepreneurial } \\
\text { UK genomics firms in comparative } \\
\text { perspective }\end{array}$ & S. Casper \\
\hline 62 & Cesagen & $\begin{array}{l}\text { Transcending the genome: the paradigm } \\
\text { shift to proteomics }\end{array}$ & Peter Glasner \\
\hline 63 & Innogen & Genomics Innovation in Scotland & Jane Bower \\
\hline 64 & Innogen & $\begin{array}{l}\text { Innovation processes in genomics industry } \\
\text { sectors }\end{array}$ & Joyce Tait \\
\hline 65 & $\begin{array}{l}\text { Centre for Economic } \\
\text { Policy Research }\end{array}$ & $\begin{array}{l}\text { GM foods: facts, mergers, business } \\
\text { practices and intellectual property }\end{array}$ & $\begin{array}{l}\text { P. Regibeau, K.E. } \\
\text { Rockett }\end{array}$ \\
\hline 66 & Cesagen & $\begin{array}{l}\text { Plant Genomics, Commercialization and } \\
\text { Environmental Knowledge: Shifting } \\
\text { cultures of scientific research }\end{array}$ & $\begin{array}{l}\text { Brian Wynne, } \\
\text { Claire Waterton }\end{array}$ \\
\hline 67 & $\begin{array}{l}\text { SATSU, York } \\
\text { University }\end{array}$ & $\begin{array}{l}\text { Pharmacogenomics, diagnostic tests and } \\
\text { clinician acceptance }\end{array}$ & Graham Lewis \\
\hline 68 & $\begin{array}{l}\text { IGBiS (Nottingham)/ } \\
\text { SATSU }\end{array}$ & $\begin{array}{l}\text { The clinical and commercial development } \\
\text { of pharmacogenetics }\end{array}$ & $\begin{array}{l}\text { Paul Martin, } \\
\text { Andrew Webster, } \\
\text { Graham Lewis }\end{array}$ \\
\hline 69 & $\begin{array}{l}\text { SATSU, York } \\
\text { University/ SPRU }\end{array}$ & $\begin{array}{l}\text { Pharmacogenetics and } \\
\text { pharmacogenomics: State-of-the-art and } \\
\text { potential socio-economic impact }\end{array}$ & Graham Lewis \\
\hline 70 & $\begin{array}{l}\text { Goldsmiths College, } \\
\text { University of London } \\
\text { and University of } \\
\text { Wales College of } \\
\text { Medicine }\end{array}$ & $\begin{array}{l}\text { Ethical factors in psychiatric drug } \\
\text { development: an archival study of the } \\
\text { ethical factors that influenced the } \\
\text { development and production of Prozac in } \\
\text { Eli Lilly \& Company Ltd }\end{array}$ & $\begin{array}{l}\text { Mariam Fraser, } \\
\text { Nikolas Rose, } \\
\text { David Healy }\end{array}$ \\
\hline 71 & $\begin{array}{l}\text { Institute for the Study } \\
\text { of Genetics, Biorisks } \\
\text { and Society, } \\
\text { University of } \\
\text { Nottingham }\end{array}$ & $\begin{array}{l}\text { Caught between science and society: food } \\
\text { and mouth disease }\end{array}$ & Brigitte Nerlich \\
\hline 72 & Cesagen & $\begin{array}{l}\text { Definitions Of Genetic Knowledge \& Pre- } \\
\text { Implantation Genetic Diagnosis: An } \\
\text { Ethnographic Study }\end{array}$ & $\begin{array}{l}\text { Sarah Franklin } \\
\text { (now at LSE) }\end{array}$ \\
\hline 73 & Warwick University & $\begin{array}{l}\text { Social Implications Of One Stop First } \\
\text { Trimester Prenatal Screening }\end{array}$ & $\begin{array}{l}\text { Gillian Lewando- } \\
\text { Hundt }\end{array}$ \\
\hline
\end{tabular}




\begin{tabular}{|c|c|c|c|}
\hline Project & Institute & Project & Project Leader(s) \\
\hline 74 & Cesagen & $\begin{array}{l}\text { The emerging politics of new genetic } \\
\text { technologies: the organisation, } \\
\text { mobilisation and inclusion of public } \\
\text { voices in the regulation of cutting edge } \\
\text { science }\end{array}$ & $\begin{array}{l}\text { Ian Welsh, Robert } \\
\text { Evans }\end{array}$ \\
\hline 75 & $\begin{array}{l}\text { Centre for } \\
\text { Environmental Risk, } \\
\text { University of East } \\
\text { Anglia }\end{array}$ & $\begin{array}{l}\text { Public Perceptions of Risk, Science and } \\
\text { Governance }\end{array}$ & Nick Pidgeon \\
\hline 76 & The Open University & $\begin{array}{l}\text { Farmers' Understandings of genetically } \\
\text { modified crops within local communities }\end{array}$ & Andy Lane \\
\hline 77 & University of Cardiff & $\begin{array}{l}\text { Inside or outside the bioscience tent? The } \\
\text { presentation of laboratory-self }\end{array}$ & A. Erkisson \\
\hline 78 & $\begin{array}{l}\text { University of } \\
\text { Liverpool/ SATSU, } \\
\text { York University }\end{array}$ & $\begin{array}{l}\text { Variability in response to warfarin: a } \\
\text { prospective analysis of pharmacogenetic } \\
\text { and environmental factors }\end{array}$ & $\begin{array}{l}\text { Munir } \\
\text { Pirmohamed, } \\
\text { Andrew Webster }\end{array}$ \\
\hline 79 & Cesagen & $\begin{array}{l}\text { Factors affecting preimplantation genetic } \\
\text { diagnosis (PGD) patient's attitudes toward } \\
\text { donation of embryos for stem cell research }\end{array}$ & $\begin{array}{l}\text { Sarah Franklin } \\
\text { (now at LSE) }\end{array}$ \\
\hline 80 & $\begin{array}{l}\text { Department of } \\
\text { Anthropology, } \\
\text { University of Sussex }\end{array}$ & $\begin{array}{l}\text { Childhood vaccination: science and public } \\
\text { engagement in international perspective }\end{array}$ & James Fairhead \\
\hline 81 & $\begin{array}{l}\text { SPRU, University of } \\
\text { Sussex }\end{array}$ & $\begin{array}{l}\text { Deliberative Mapping: Piloting an } \\
\text { Innovative Public Consultation Process } \\
\text { with the Case of Xenotransplantation and } \\
\text { Organ Failure }\end{array}$ & Andy Stirling \\
\hline 82 & Cardiff University & $\begin{array}{l}\text { Collective learning in knowledge } \\
\text { economies: milieu or market? }\end{array}$ & Philip Cooke \\
\hline 83 & $\begin{array}{l}\text { SPRU, University of } \\
\text { Sussex }\end{array}$ & $\begin{array}{l}\text { Public Perceptions of BSE and CJD Risk } \\
\text { in Europe, their interplay with Media, } \\
\text { Policy Initiatives and Surveillance Issues }\end{array}$ & Erik Millstone \\
\hline 84 & IGBiS (Nottingham) & $\begin{array}{l}\text { Decision-Making by Women At-Risk of } \\
\text { Hereditary Breast And Ovarian Cancer }\end{array}$ & Emma Rowley \\
\hline 85 & PEALS & Cumbria Genetics Database & Erica Haimes \\
\hline 86 & IGBiS (Nottingham) & The Regulation of DNA Databases & Paul Martin \\
\hline 87 & $\begin{array}{l}\text { University of } \\
\text { Liverpool }\end{array}$ & $\begin{array}{l}\text { How do users interpret probabilistic } \\
\text { pregnancy screening information? }\end{array}$ & R. S. Bramwell, \\
\hline 88 & IGBiS (Nottingham) & The Rhetoric of Genes & Craig Hamilton \\
\hline 89 & Cesagen & $\begin{array}{l}\text { Explanation in genetics: causality and } \\
\text { accountability in complex disorders }\end{array}$ & $\begin{array}{l}\text { Angus Clarke, } \\
\text { Srikant Sarangi, } \\
\text { Ruth Chadwick }\end{array}$ \\
\hline 90 & University of Surrey & Attitudes to genomics (Genomics survey) & R. Shepherd \\
\hline 91 & University of Surrey & $\begin{array}{l}\text { Public understanding of genomics and the } \\
\text { dynamics of attitude change }\end{array}$ & P. Sturgis \\
\hline 92 & IGBiS (Nottingham) & $\begin{array}{l}\text { The role of imagery and emotions in } \\
\text { decisions concerning GM food }\end{array}$ & Ellen Townsend \\
\hline 93 & PEALS & $\begin{array}{l}\text { A comparative study of embryo donors' } \\
\text { and non-donors' views on embryo } \\
\text { experimentation for preimplantation } \\
\text { genetic diagnosis and stem cell therapy }\end{array}$ & $\begin{array}{l}\text { Erica Haimes, } \\
\text { Alison Murdoch }\end{array}$ \\
\hline 94 & IGBiS (Nottingham) & $\begin{array}{l}\text { New Social Movements, Popular Media } \\
\text { and Policy-Making }\end{array}$ & Paul Martin \\
\hline
\end{tabular}




\begin{tabular}{|c|c|c|c|}
\hline Project & Institute & Project & Project Leader(s) \\
\hline 95 & IGBiS (Nottingham) & $\begin{array}{l}\text { Patients' constructions of familial } \\
\text { hypercholesterolaemia }\end{array}$ & Kate Weiner \\
\hline 96 & Cesagen & Genetics, Health and Identity & $\begin{array}{l}\text { Angus Clarke, } \\
\text { Srikant Sarangi }\end{array}$ \\
\hline 97 & Egenis & $\begin{array}{l}\text { The relationships between theories of } \\
\text { groups memberships and inter-group } \\
\text { attitudes }\end{array}$ & Thomas Morton \\
\hline 98 & Innogen & $\begin{array}{l}\text { Talking about stem cells: The Social } \\
\text { Dynamics of Public Engagement in Stem } \\
\text { Cell Research }\end{array}$ & $\begin{array}{l}\text { Sarah } \\
\text { Cunningham- } \\
\text { Burley, Sarah } \\
\text { Parry, Wendy } \\
\text { Faulkner, Austin } \\
\text { Smith }\end{array}$ \\
\hline 99 & Egenis & $\begin{array}{l}\text { Complex Risks and Testing for } \\
\text { Thrombophilia: A case study on genes and } \\
\text { common disease }\end{array}$ & Paula Saukko \\
\hline 100 & $\begin{array}{l}\text { Goldsmith's } \\
\text { College/SATSU }\end{array}$ & $\begin{array}{l}\text { Xenotransplantation: Risk Identities and } \\
\text { the Human / Non Human Interface }\end{array}$ & Mike Michael \\
\hline 101 & $\begin{array}{l}\text { SPRU, University of } \\
\text { Sussex }\end{array}$ & Chemical / Biological Warfare & $\begin{array}{l}\text { Julian Perry } \\
\text { Robinson }\end{array}$ \\
\hline 102 & IGBiS (Nottingham) & $\begin{array}{l}\text { The Regulation of Small Biotech Start-Up } \\
\text { Companies in Scotland and Norway }\end{array}$ & Robert Dingwall \\
\hline 103 & $\begin{array}{l}\text { SPRU, University of } \\
\text { Sussex }\end{array}$ & $\begin{array}{l}\text { Study on benchmarking of public } \\
\text { biotechnology policy }\end{array}$ & Pari Patel \\
\hline 104 & Cardiff University & $\begin{array}{l}\text { The Construction Of Risk Estimates In A } \\
\text { Cancer Genetics Clinic }\end{array}$ & Lindsay Prior \\
\hline 105 & Cesagen & $\begin{array}{l}\text { Genetic Screening For Susceptibility To } \\
\text { Disease: The Case Of Haemochromatosis }\end{array}$ & Paul Atkinson \\
\hline 106 & Brunel University & $\begin{array}{l}\text { The impact of genetic risk information on } \\
\text { families of Pakistani origin referred for } \\
\text { genetic counselling }\end{array}$ & $\begin{array}{l}\text { Alison Shaw, Jane } \\
\text { Hurst }\end{array}$ \\
\hline 107 & University of Sussex & $\begin{array}{l}\text { The ethical and public policy implications } \\
\text { of the new genetics and transgenics in the } \\
\text { carcinogenic risk assessment of } \\
\text { pharmaceuticals }\end{array}$ & John Abraham \\
\hline 108 & $\begin{array}{l}\text { King's College, } \\
\text { University of London }\end{array}$ & Mapping stem cell innovation in action & Clare Williams \\
\hline 109 & $\begin{array}{l}\text { University of the } \\
\text { West of England }\end{array}$ & $\begin{array}{l}\text { Forgotten Fetuses - A Sociocultural } \\
\text { analysis of the use of fetal stem cells }\end{array}$ & $\begin{array}{l}\text { Julie Kent, Naomi } \\
\text { Pfeffer }\end{array}$ \\
\hline 110 & $\begin{array}{l}\text { IgBis } \\
\text { (Nottingham)/SATSU }\end{array}$ & $\begin{array}{l}\text { Haematopoietic Stem Cells: The } \\
\text { Dynamics of Expectations in Innovation }\end{array}$ & $\begin{array}{l}\text { Paul Martin, Nik } \\
\text { Brown }\end{array}$ \\
\hline 111 & Cardiff University & $\begin{array}{l}\text { Medical Device Governance: Regulation } \\
\text { of Tissue Engineering in the UK and EU }\end{array}$ & Alex Faulkner \\
\hline 112 & IGBiS (Nottingham) & The Regulation of Cloning & Paul Martin \\
\hline 113 & $\begin{array}{l}\text { University of } \\
\text { Edinburgh }\end{array}$ & $\begin{array}{l}\text { Health, life insurance and financial } \\
\text { inclusion }\end{array}$ & P.G. Bennett \\
\hline 114 & IGBiS (Nottingham) & $\begin{array}{l}\text { Popular Media and the Production of } \\
\text { News about Biorisk: } \\
\text { 'Health risks, body risks and food } \\
\text { presentation in women's general interest }\end{array}$ & Kathy Wilkinson \\
\hline
\end{tabular}




\begin{tabular}{|c|c|c|c|}
\hline Project & Institute & Project & Project Leader(s) \\
\hline & & magazines' & \\
\hline 115 & $\begin{array}{l}\text { University of } \\
\text { Plymouth }\end{array}$ & $\begin{array}{l}\text { Nanotechnology and news production: } \\
\text { scientists', journalists', and editors' views }\end{array}$ & A. Anderson \\
\hline 116 & $\begin{array}{l}\text { University of } \\
\text { Nottingham }\end{array}$ & $\begin{array}{l}\text { Implicit models of evolution in broadcast } \\
\text { wildlife and nature programmes }\end{array}$ & $\begin{array}{l}\text { M.E. Alridge, } \\
\text { Robert Dingwall }\end{array}$ \\
\hline 117 & Cesagen & $\begin{array}{l}\text { Communicative frames in counselling for } \\
\text { predictive testing }\end{array}$ & $\begin{array}{l}\text { Srikant Sarangi, } \\
\text { Angus Clarke }\end{array}$ \\
\hline 118 & IGBiS (Nottingham) & $\begin{array}{l}\text { The meaning of genetics - a project based } \\
\text { on corpus linguistics }\end{array}$ & Craig Hamilton \\
\hline 119 & IGBiS (Nottingham) & $\begin{array}{l}\text { Genomics Discourse - Special Journal } \\
\text { Edition of Discourse \& Society }\end{array}$ & Brigitte Nerlich \\
\hline 120 & University of Reading & $\begin{array}{l}\text { The presentation of GM crop research to } \\
\text { non specialists: a case study }\end{array}$ & $\begin{array}{l}\text { G. Cook, P.T. } \\
\text { Robbins }\end{array}$ \\
\hline 121 & University of Reading & $\begin{array}{l}\text { The discourse of the GM food debate: } \\
\text { how language choices affect public trust }\end{array}$ & $\begin{array}{l}\text { G. Cook, P.T. } \\
\text { Robbins, E. Pieri }\end{array}$ \\
\hline 122 & Egenis & Genomics as a Source of Status Markers & Barry Barnes \\
\hline 123 & Egenis & The Cultural History of Heredity & $\begin{array}{l}\text { Staffan Mueller- } \\
\text { Wille }\end{array}$ \\
\hline 124 & Egenis & $\begin{array}{l}\text { Semantic Drift in the Dissemination of } \\
\text { Genomics }\end{array}$ & $\begin{array}{l}\text { Christine } \\
\text { Hauskeller }\end{array}$ \\
\hline 125 & Cesagen & Media, Culture and Genomics & $\begin{array}{l}\text { Jenny Kitzinger, } \\
\text { Maureen McNeil }\end{array}$ \\
\hline 126 & Egenis & $\begin{array}{l}\text { Patenting and the utility of genomic } \\
\text { knowledge }\end{array}$ & Jane Calvert \\
\hline 127 & University of Exeter & Ambiguity and optimism & David Kelsey \\
\hline 128 & University of York & $\begin{array}{l}\text { Doing embryo ethics: safety and efficacy } \\
\text { in research and practice }\end{array}$ & $\begin{array}{l}\text { Anne Kerr (now at } \\
\text { University of } \\
\text { Leeds) }\end{array}$ \\
\hline 129 & Cesagen & $\begin{array}{l}\text { Reconfigurations of Human/Animal } \\
\text { Relations in Genomics and Beyond } \\
\text { (ROAR) }\end{array}$ & $\begin{array}{l}\text { Richard Twine, } \\
\text { Alan Holland }\end{array}$ \\
\hline
\end{tabular}

\section{(i) Globalisation, Development and Genomics}

In the 1960's, Marshall McLuhan coined the term 'global village' when analysing the effects of the increased interconnectivity of global society through information technology. ${ }^{6}$ Four decades later, globalisation has occurred not only through the compression of space and time by information technology but also via unprecedented levels of cross-border cultural and economic exchange.

Central to globalisation has been the reduced power of individual nation-states over global and domestic politics, economics and culture, as well as the rise of entities such as trans-national corporations, public-private partnerships, NGOs or the supragovernmental European Union. The rise of these organisations has profoundly influenced the way in which societies are governed (as will be further discussed in III (ii)). Some also argue that globalisation's 'new world disorder" ${ }^{7}$ has lead to 
greater disparity between rich and poor, northern and southern countries. As some feel increasingly empowered, others feel disempowered. Whether globalisation tends towards such polarisation is an open question; but disputes over the global commercialisation of genetically modified organisms (GMOs), for example, may be seen as indicative of the tensions created by globalisation:
'Globalisation...connotes, at one extreme, confident utopian fantasies of omnipotence, and at the other, a sense of things falling apart, of centres that do not hold, and of a radically diminished sense that one's voice, one's actions, or even one's existence matters or makes a difference to the way things are. And perhaps nowhere is this more apparent than in contemporary responses to biotechnology.'

Thus studies of globalisation are aided by examining the social, political and economic issues surrounding biotechnology, and vice versa. This applies across the world, but arguably, the most urgent issues created by globalisation centre around the economic and health impacts on people in developing countries. ${ }^{9}$ Studies of 'development', which suggest that technologies including biotechnologies have played a central but controversial role for the past half-century, ${ }^{10}$ are thus highly relevant and properly address the present and future implications of genomic science.

Focal points for such studies include analyses of the capacity of developing nations to research, develop, apply and/or govern biotechnologies. ${ }^{11}$ Moreover, building developing countries' capacities to assess for themselves the risks and benefits that biotechnologies pose is another important issue related to development. Of course not all such countries may be grouped together, as they have widely varying expertise in employing biotechnologies. However, in the context of development, biotechnologies remain highly controversial. Industrialised countries have, notoriously, had difficulties in establishing regulatory systems to govern the risks that biotechnologies may pose and in coming to consensus (nationally and internationally) on which biotechnologies should or should not be permissible; the challenges for more newly industrial countries, yet to develop biotechnology sectors, are likely to be more acute.

\section{UK Research Addressing Globalisation, Development and Genomics}

Of the research programmes listed in Table 1, a relatively minor proportion are devoted to issues directly related to globalisation and development. ${ }^{12}$ Most concentrated are a series of projects within the ESRC Genomics Network (Innogen, Cesagen, Egenis), which are broadly exploring how 'modern biotechnology can be translated into practice' given many constraints, such as lack of infrastructure, lack of 'capacity', and political and economic obstacles to technology transfer. ${ }^{13}$ These projects comprise a critical analysis of the types, characteristics, operations and impacts of various development public and/or private initiatives. ${ }^{14}$ The diffusion of knowledge/technology and its flow between various actors (e.g. scientists, farmers, businesspeople) is an important theme in this research. Another important theme is the rights of local populations, such as indigenous people in the Amazon, where one project is aimed at understanding the Amazonian perspective to inform policy 
debates about issues such as indigenous peoples' rights, prior informed consent or benefit-sharing. ${ }^{15}$

Other research programmes, concerned with the dangers posed by the globalisation of biomedical $\mathrm{R} \& \mathrm{D}$, focus on the potential exploitation of those used as subjects for research or as donors of biological materials. Whilst these projects are not focussed on issues arising solely from genomic research and medicine, the promise of genomic medicine and the globalisation of R\&D makes these enquiries highly pertinent to this report. Research at Cesagen is seeking to identify and anticipate some of the key bioethical implications of globalisation processes. ${ }^{16}$ Two projects sponsored by the Wellcome Trust are analysing current practices in specific developing countries aimed at seeking informed consent, and how these practices might be enhanced and supported. ${ }^{17}$ This builds upon earlier research such as the 2002 report, The Ethics of Research Related to Healthcare in Developing Countries, published by the Nuffield Council on Bioethics, in drawing attention to the challenges in ensuring that globalisation of technology is sensitive to issues of justice as they occur in specific and local contexts. ${ }^{18}$

\section{(ii) Governance, Policy, Publics \& Genomics}

As discussed above, globalisation processes have arguably contributed to an alteration in the role and power of nation-states. This alteration has been so profound, it is suggested, that government (in the sense of the formal exercise of executive powers by regularly constituted political authorities) is no longer the determinant of public affairs. Where the state is hollowed out, ${ }^{19}$ room has been created for more actors to emerge. The boundary between state and society has blurred:

'...no single agency, public or private, has all the knowledge and information required to solve complex problems in a dynamic and diverse society, and no single actor has the power to control events in a complex and diverse field of actions and interactions. ${ }^{20}$

In this state of affairs:

‘...social-political governance and governing are not primarily looked upon as acts of governments, but as more or less continuous processes of interaction between social actors, groups and forces and public or semi-public organisations, institutions or authorities.

The term 'governance' is used to mark this 'change in the meaning of government' and to refer 'to the new method by which society is governed. ${ }^{22}$

In these circumstances, national governments no longer dictate policies so much as steer them. One of governments' key roles within governance becomes then, to create a forum in which policy-making can occur and decisions taken. Within this forum, transient and unforeseen alliances tend to mobilize around specific issues, creating loose and ad hoc policy networks. ${ }^{23}$ But just as there is 'a multitude of autonomous actors who create patterns of structured cooperation despite the absence of a central organizing authority', ${ }^{24}$ so there is, in fact, a multitude of fora in which 
they act and engage. If 'governance is about the ways and means in which the divergent preferences of citizens are translated into effective policy choices, about how the plurality of social interests are transformed into unitary action and the compliance of actors is achieved', ${ }^{25}$ then it must account for a transformation which emerges from numerous overlapping and competing fora, including regional and national governments, the European Commission, international agencies and authorities (e.g. OECD, UNESCO, GATT, the Cartagena Protocol on Biodiversity) and so on.

\section{The Governance of Genomics}

The plurality of actors involved in governance has great significance for genomics. Biotechnologies, like other new bodies of knowledge, carry within them the 'potential for new forms of power, regulation and surveillance. Professing to offer new ways to reproduce and "improve" our bodies, our minds and our environments, such techniques raise new questions about the nature of human existence and the type of social relationships we want to perpetuate. ${ }^{26}$ These questions are profoundly difficult, and their resolution is certainly rendered no easier by the wide range of actors or stakeholders who are implicated in contemporary patterns of governance, with its multiple fora. Consequently systems of governance-and within them, regulatory systems, which are often at the forefront of debates surrounding biotechnolog $\mathrm{y}^{27}$ (as will be discussed in III (iii)) — are placed under enormous strain as they confront these issues.

Salter and Jones have helpfully summarised some of the critical challenges related to the governance of the 'new' genetics:

'Civil society, science and industry all have a political interest in the creation of human genetics knowledge, its industrial application and its therapeutic potential. Sometimes those interests may overlap, on other occasions they may be completely incompatible. It is the political function of both the state and the supra-state regulation of human genetics to find a way of negotiating, and hopefully resolving, the tensions between the different interests. In so doing, the regulatory institutions concerned face an array of shifting political forces which place conflicting demands on the apparatuses of governance in terms not only of the outputs required but also the means by which these outputs are achieved. The legitimacy of the policy process itself - that is, the way in which policy is produced through agenda setting, formulation, implementation and evaluation - may be called into question. 28

Thus as governments attempt to foster processes for resolving debates rather than issues, policy processes as well as policy outcomes are likely to be contested. As this happens, space is created for new policy networks/communities to arise and pursue particular agendas. One example that has been cited is the rise of bioethics in EU policy-making - as science-based governance (and risk assessments) has been increasingly challenged, a 'new transnational policy network' of bioethicists emerged, and groups such as the European Group on Ethics in Science and New Technologies (EGE) are now part of the institution of biotechnology policy making. ${ }^{29}$ 
There is, however, another layer of complexity to be added to the consideration of governance as it relates to the web of concerns raised by the advance and application of the new genetics. In the wake of scientific controversies surrounding topics such as BSE, GMOs or MMR vaccines, the scientific authority of 'expert' institutions has diminished, leading, so it has been argued, to crises of public trust in key institutions of governance. ${ }^{30}$

Previously, a common argument made by such governance institutions was that the public, if it properly understood science, would embrace rather than reject new technologies like GM crops. This viewpoint (resting on the so-called 'deficit model') has been rejected by those who insist that the public does not simply or typically misunderstand science, but rather assesses it by reference to a variety of different frames of meaning ${ }^{31}$ - and not just by reference to the "meaning of risk as defined by science'. ${ }^{32}$ Against the deficit model, it is now commonly asserted that public ambivalence towards new technologies is neither necessarily nor typically the result of misunderstanding or wilful rejection, but of alternative concerns and modes of appraisal.

This perspective has been influential. Governments and social scientists alike have recently spent much energy arguing for and exploring means of 'opening-up' policymaking to the public. ${ }^{33}$ A prominent example is the UK government's GM Nation? exercise, which was intended to provide one of three strands of evidence to contribute towards decisions on whether or not to commercialise GM crops-its stated objective was to 'improve the evidence-base, and to create a dialogue between all aspects of opinion on GM. ${ }^{34}$

Importantly, despite its intentions, GM Nation? has been criticised for failing to achieve its objectives. According to one commentary, the debate did not so much engage the public, as attract a small and unrepresentative sample of campaigners. ${ }^{35}$ It was, according to another appraisal, largely ignored by the wider population. ${ }^{36}$

The House of Commons' Select Committee on Environment, Food and Rural Affairs (EFRA) questioned the depth and seriousness of the good intentions which were said to have led to the exercise: "the Government...must allay the suspicion that, having agreed to undertake a public debate, it did as little as it could to make it work. ${ }^{37}$ The Committee is not alone in harbouring this suspicion, and there has been a more general concern that although governments acknowledge the importance of understanding public attitudes to new research and fostering public discussion of the deployment of new technologies, in practice they continue to employ the deficit model. ${ }^{38}$ Whether public engagement will emerge as a 'rhetorical concession, ${ }^{39}$ or a significant transformation of biotechnology governance remains to be seen.

Consequently, core questions for the future application of genomics and genomic technologies are these: what system of governance will emerge to shape the development of this field? Which actors will be influential within this (undoubtedly complex) system? How will scientific expertise and public understandings be accommodated? And what particular challenges may genomics itself pose to emerging or established patterns of governance? 
One particular challenge is likely to concern the boundaries, for example, between individual and public health, and the responsibilities for each. It is often noted that the new genetics may lead to the framing of what can be thought of as public health issues (such as heart disease) as individual problems (albeit that individuals may then be deemed to have a public duty to ascertain their genetic risks). ${ }^{40}$ Yet, paradoxically, the identification and characterisation of individual risks may well depend on public screening programmes or on vast public projects of data gathering (such as UK Biobank). How will systems of governance manage the borders of public and private interest? If citizens are ambivalent towards scientific authorities, how likely are they to participate in or endorse genetic-based public health programmes, particularly when commercial interests are often perceived to be driving forces behind such programmes ${ }^{41}$ Are present practices of informed consent sufficiently robust to cope with the particular challenges of gathering and using genetic data, and to protect individuals against the state or corporations? And can such protection be achieved without loss to the public goods which are at stake in public health measures or programmes?

\section{Summary of UK-based Research Addressing Governance, Policy, Publics and Genomics}

The governance of existing and emerging genetic technologies, and the way in which (and degree to which) these technologies are forcing governance systems to adapt, is the focus of significant attention. ${ }^{42}$ Some of these projects are focussed on describing, mapping and/or understanding the evolving governance systems relating to existing and new genetic technologies, such as stem cells, GMOs and pharmacogenomics. ${ }^{43}$ This may involve focussing on changing patterns in networks of governance and how they might influence regulatory standards. ${ }^{44}$

As discussed earlier, public trust, engagement and understanding of science are critical to analysis of governance, genomics and public policy. The projects focussed on these issues ${ }^{45}$ underscore this point in examining, for example, 'how far scientific, expert-driven risk assessment techniques can be reconciled with deliberative approaches to public consultation'. ${ }^{46}$ Thus an appreciation of public understandings or perceptions of risk is important, and this has been the focus, from varying perspectives, of significant research. ${ }^{47}$ Equally important are assessments of various public engagement techniques, a key element of research examining the social dynamics of stem cells. ${ }^{48}$

Public understandings of risk also tie-in with research into public understanding of, and attitudes towards, different aspects of genetic medical services and initiatives. One project argues that people's notions of citizenship, consumption and expertise will inform a fresh understanding of 'genetic subjecthood', and thus, it is hoped, contribute to more informed and sensitive policy-making. ${ }^{49}$ Similarly, the views of different patient groups (e.g. people receiving pre-implantation genetic diagnosis or IVF treatments ${ }^{50}$ ) are expected to "provide practical feedback to clinical scientists, practitioners, and policy-makers concerned with genetic and reproductive medicine' ${ }^{51}$ To this end, a few projects run through the ESRC Innovative Health Technologies programme have demonstrated that clinical/professional and 'lay' understandings of risk produce interpretations which may overlap but are also 
divergent. ${ }^{52}$ Such findings draw attention to, for example, the need for careful consideration of how genetic counselling is conducted. ${ }^{53}$ Meanwhile, as it has been commonly argued, there may be benefits to 'opening' science to publics at earlier stages. Thus patient attitudes to genetic testing, for example, may usefully inform an algorithm to help physicians prescribe safe dosage of warfarin, which is the focus of social research studying pharmacogenetics. ${ }^{54}$

As previously mentioned, the emergence of bioethics is an influential aspect of contemporary governance of the 'new genetics' and thus as an important element in policy-making. Indeed, a Europe-wide project with its UK base at Cesagen is examining the institutionalisation of ethics in science policy. ${ }^{55}$ Various other projects are specifically and varyingly focussed on ethical and governance issues arising from genetic research and services. ${ }^{56}$

A central norm of much recent bioethics has been that of 'informed consent', and the understanding and application of this norm is likely to be central to the future governance of medical interventions emerging from or advanced by genomics. Projects have explored social and ethnic differences to consent and the problems posed by practices of individual consent to procedures which yield information which may be of familial significance. ${ }^{57}$ Views and preferences relating to the very specific problems around consent and other aspects of genetic research involving children in the UK are also being investigated. ${ }^{58}$ Similarly the specific problems raised for procedures of consent outside the cultural context in which they have arisen are a concern. ${ }^{59}$ An analysis of how non-professionals understand bioethics may help to address whether, and how much, significance the public places on consent as compared to the discipline of bioethics or current systems of clinical governance. $^{60}$

\section{(iii) Regulation, Innovation and Genomics}

Globalisation and governance (as against government), provide the context for both the regulation of genomics and its related technologies, and for further innovation in this field. Of course the choices that a society makes about governing new technologies are often manifested in the regulatory arena, and these choices are subject to myriad potential conflicts of objectives or interests, such as between ensuring consumer safety or promoting national economic competitiveness. The regulation of technologies, then, becomes a key area of controversy (and consequently of social science research): 'Governance in its regulatory form is the political theatre where the pressures for change from the arenas of science and industry meet the inchoate needs, values and sensibilities of civil society. ${ }^{, 61}$

Consumer groups, environmental groups, public health activists, patient advocacy organisations, industry and science all attempt to influence, shape or determine regulatory outcomes. Importantly, however, these groups influence more than regulation of new technologies; the socio-political environment they create also shapes the trajectory of new technologies: 
'Assessing the 'impact' of a new technology cannot...be simply separated from either the process of technical innovation or debates about public policy. The way in which social problems are anticipated and resolved influences the behaviour of actors, such as regulators and firms, and this in turn shapes the development of the technology. ${ }^{62}$

Regulation and innovation, therefore, are intrinsically linked. Understanding the processes influencing one will also contribute an understanding of the other. Both, from varying perspectives, have been the focus of substantial research.

\section{Regulation \& Genomics}

One thing regulatory regimes seek to regulate is risk. Biotechnologies in general (and those which may emerge from the further development of genomics) are centrally associated with the modern risk environment as Giddens characterised it, which is 'structured by humanly created risks. ${ }^{63}$ What is significant about these new risks from biotechnology, however, is that in a variety of ways they test and challenge existing regulatory regimes.

It is the case, of course, that these technologies may pose risks to the environment and risks to human health which are, in a manner of speaking, quite familiar to regulatory regimes. But this is not always the case. Some risks which may emerge from genotyping (e.g. the genetic risk of, or susceptibility to, breast cancer) are quite difficult to conceptualise, express and handle. Other risks may be introduced by biotechnologies (such as gene flow from GM crops) and not straightforwardly estimated or assessed. Such risks may not only create new uncertainties. They may also transcend the jurisdictions of existing regulatory institutions, creating the need for new forms of expertise as well as regulatory agencies. ${ }^{64}$ All this occurs in the wider context described in III (ii), in which, so it is commonly argued, the public has lost trust in traditional institutions of governance, not least the scientific authorities. This web of uncertainty around risk has created what Brown \& Michael have called 'meta-risks' - 'the social and political risks that are incurred when decisions are made about how to go about assessing technical risks. ${ }^{65}$

Jasanoff has argued that technical decision-making often incorporates socially or politically contingent judgements, such as those concerning appropriate levels of risk. ${ }^{66}$ This is concealed, however, by the maintenance of a false boundary between 'science' and 'policy' with the result that there remains little room for accountability and public scrutiny. ${ }^{67}$ The USA's Food \& Drug Administration, as with other agencies, has maintained this boundary, so she argues, in order to 'harness the authority of science in support of its own policy preferences. ${ }^{, 68}$

Insofar as the new biotechnologies have exposed the significance and depth of uncertainties surrounding risks and their assessment, there may be a new and robust awareness of the role of values and interests in shaping 'regulatory science'. However that may be, new and emerging biotechnologies will pose afresh the questions this section has introduced: How are regulatory issues framed? How is 'science' or 'evidence' used in regulatory decision-making? How are regulatory systems evolving to cope with new biotechnologies? How are stakeholders 
organising in order to attempt to influence regulation and where are the boundaries between experts and non-experts drawn?

\section{Innovation and Genomics}

As discussed earlier, regulatory policies, and the multitude of actors attempting to influence them, shape the trajectories of new technologies. More generally, it is essential to recognise that innovation does not happen in isolation. Rather, it occurs in so-called sociotechnical systems in which social actors both shape and are shaped by technologies, ${ }^{69}$ and thus in the context of the issues of globalisation and governance.

Some actors promote the notion of a 'biotechnology revolution ${ }^{, 70}$ which is to be accepted and embraced. In the case of genomics and genomics-related technologies, potential social problems and risks which they may bring are reckoned by these advocates to be outweighed by the substantial potential benefits to society which they are said to offer. Government and industry have become strong advocates of biotechnology and link it to national wealth: agencies such as the UK Government's Department of Trade and Industry (DTI) emphasise the strategic importance of domestic biotechnology industries through funding publications such as 'Bioscience 2015: Improving National Health, Improving National Wealth' ${ }^{71}$ In another report, 'Genome Valley: The Economic Potential and Strategic Importance of Biotechnology in the UK', the DTI argues:

'It will be important for Government to continue...to take action to ensure that entrepreneurial, fiscal and regulatory frameworks are set in a way which makes the UK the chosen location for major internationally mobile investments in biotechnology. ${ }^{, 72}$

This report stressed the necessity of a 'balanced regulatory regime ${ }^{73}$ but also addressed additional important factors influencing innovation, such as intellectual property rights, infrastructures fostering innovation (e.g. biotech clusters) and academic spin-out companies. These are all areas that have been the focus of policies to stimulate innovation in biotechnology.

Yet despite (or perhaps because of) the intensive emphasis placed on fostering innovation in biotechnology, an increasing number of observers are questioning the biotechnology 'revolution' - it seems clear that, to date, there have been far fewer new genomics-based products than originally expected. ${ }^{74}$ The dearth of new products puts additional pressure on a pharmaceutical industry that had already been undergoing a significant transformation due to such factors as changing regulatory environments, negative publicity, and the patent expiration of many profitable products. $^{75}$

With industry facing such pressures in the more lucrative markets, the question of how to stimulate innovation that will benefit developing countries remains critical. As WHO has argued, global research is determined by the markets of wealthy rather than developing countries. ${ }^{76}$ If markets cannot be counted on to develop drugs sorely needed by developing nations, then other mechanisms may be necessary if innovation is to serve the needs of the developing world and prevent the further 
exacerbation of inequalities. Among the possible mechanisms, the following are prominent: private-public partnerships, dedicated funds for research and development, tax incentives, differential drug pricing and more equitable usage of intellectual property rights. ${ }^{77}$

In summary: how and why new technologies are regulated closely relates to underlying beliefs about how societies should be organised.78 As such, discussions about regulation often comprise the focal point for controversy and contestation amongst actors with competing and conflicting interests and objectives. Regulatory systems are also one of the forces shaping and being shaped by innovative new technologies. Since governments and industry have invested large sums to ensure that domestic biotechnology industries can contribute to national and international health and wealth, both regulatory systems and the way in which innovation is promoted have been, and will continue to be, key subjects for social science research.

\section{UK Research Addressing Regulation, Innovation and Genomics}

Some of the UK-based projects studying risk governance, as one aspect of regulation, have already been described. In particular reference was made to projects focussed on examining the influence of various stakeholders in shaping regulatory systems relating to specific biotechnologies. ${ }^{79}$ Other research seeks to understand the development of regulatory systems as they cope with issues thrown up by research informed by the new genetics, such as xenotransplantation or fetal stem cells. ${ }^{80}$ Regulatory institutions themselves may play a role in 'stabilising' new technologies, and this is also the focus of research examining institutions like stem cell banks. ${ }^{81}$

The dynamic interrelationship between innovation and regulation has been the subject of work in the sociology of expectations. ${ }^{82}$ Specifically in relation to stem cells, the project will consider how expectations of the application of technologyexpectations held by academia, industry and government - shape not only the development of the technology, but also of perspectives and attitudes towards its regulation. Plainly, if expectations of the potential 'goods' of a technology are overstated, this might lead regulators to accept undue risks. Thus, study of the nature and character of risk assessment of, for example, pharmaceuticals is a key area of research contributing to a better understanding of unfolding patterns of regulation and innovation, and so to an understanding of how a medical technology may or may not diffuse from the 'bench to bedside'. ${ }^{83}$ One such new technology or approach which is the subject of considerable expectation is pharmocogenomics, and the uptake of new diagnostic-based therapies based on pharmocogenomics is the focus of research that will look in particular at similarities and differences in regulatory assessment in the US, Europe and Japan. ${ }^{84}$ Meanwhile, additional research is analysing the influence of regulatory agencies on the development of pharmaceutical products, and, more broadly, some research is considering whether public accountability and commercial success can be reconciled by regulatory systems. ${ }^{85}$

Finally, a wide range of research is studying the factors influencing innovation within industry, and the nature, direction and management of such innovation. Some ${ }^{86}$ are focussed on the impact of genomic and post-genomic technologies on innovation within industry while others ${ }^{87}$ are studying trends in patenting and how 
they relate to public policy and innovation. Others yet are focussing on the influence of various factors on academic and industrial research and development, such as clustering, multidisciplinary interactions or the broader macroeconomic environment. $^{88}$

\section{Part IV - Directions for Future Research}

As the social science research described in Part Three proceeds, the Genomics Forum has had the opportunity, as a newer part of the UK landscape, to take a step back and consider the overall direction of this research. In doing so, three broad and related areas are identified as providing important ground for future engagement. (i) The first area, taking note of the context in which much current social science research is located, involves a clarification of the nature of the contribution of social sciences to policy-making in genomics.

(ii) The second area is related to issues which arise from the first, and involves social science in the further development of, and participation in, inter-disciplinary projects addressing central policy questions, working with, for example, law and economics. (iii) The third area, whilst noting the importance of policy questions, also notes the constraints which a focus on questions of immediate policy significance can place on social science, and involves the development of wider social scientific reflection on the meaning of genomics and post-genomic science for human self-understanding.

\section{(i) The Context or Framing of the Social Science of Genomics}

The contribution of social science to understanding the significance, implications and consequences of the rise of genomics is being made in intimate connection with the intellectual contribution of other disciplines, and chiefly in connection with the contributions of ethics and law. This connection was formalised in terms of funding by the decision of the Human Genome Project to devote a proportion of its vast resources to a stream of work on ethical, legal and social aspects of the sequencing of the genome. This formal linking of different disciplines and research interests is reflected in the acronyms ELSA (for ethical, legal and social aspects) or ELSI (ethical, legal and social implications), which are now accepted shorthand for referring to a range of non-scientific questions posed by science and technology.

That social science is operating in this context is highly significant in considering the framing of an agenda for future research. Whilst the linking of social science with ethics and law has been appropriate in certain ways, it is possible that this same linkage has threatened to conceal the particular contribution that social science properly makes to the field. There is a danger that the invention and institutionalising of work on ELSA/ELSI of genomics, has hidden rather than highlighted the contribution of the social sciences. Certainly, and at the very least, it is noticeable that bioethics has tended to dominate the framing of the ELSA/ELSI agenda.

It is important, therefore, for social science not simply to accept this situation as given, but to take steps to clarify its disciplinary integrity and its interdisciplinary relationships. In the context of the 'ELSA/ELSI-fication' of the critique of science, in the future, such steps will be a vital element in securing a proper hearing for the subject in the future in the policy arena. What is needed, therefore, is an attempt to 
clearly state the nature of social science's contribution to the understanding and analysis of genomics and to clarify the particularity of this understanding by placing alongside it accounts from philosophy and law. But these discrete statements would not be enough. The framing of the contribution of social science in ELSA/ELSI programmes demands systematic thinking not only about the specific contribution of the social sciences, but also an attempt to describe how the social sciences complement (or challenge) the other elements which have become institutionalised partners in the policy debate. ${ }^{89}$

\section{(ii) Social Science and Interdisciplinarity in Genomics}

The political reality of the ELSA/ELSI context currently demands that the social sciences work with and alongside other disciplines to ensure that the social sciences' particular insights and concerns are acknowledged. Two areas that seem worthy of further attention by social scientists, are those concerning intellectual property regimes and the evaluation of genetic services/interventions in the field of human health. These two areas are central to the development and application of genomic science and as such are deserving of continued critical attention from the social sciences.

It is a familiar point that different regimes for the protection of intellectual property will have crucially different consequences for the course of innovation, research and development - and not only 'development' in the R\&D sense, but in the sense of 'international development'. But equally significant for the course of development of genomic science are choices relating to the recognition and protection of intellectual property, and both national and international budgetary decisions regarding which of the applications of genomic science to human health receive funding. As the previously cited WHO Report (Genomics and World Health) makes clear, critical questions will need to be addressed to the claims of genetic medicine for scarce health resources in developing economies; but the same evaluative questions will have to be asked by any system of health provision in which there are competing claims for health resources. Thus the NHS will have to ask what priority in funding should be given to the new possibilities opened up by genomics for Pre-implantation Genetic Diagnosis (PGD), or to so-called 'personalised medicine' based on pharmocogenomics, or to individual or population genetic screening or testing. The answers to these particular questions are in and of themselves highly significant, and like the answers to questions about the merits of different regimes of protection for intellectual property, have the added significance of shaping the equally socially important development path of a whole raft of new technologies.

If the framing of the larger ELSA/ELSI debate should be subject to critical questioning, so too should the detailed treatment of individual policy questions within the agenda. If the first requires that social science itself stand back from the entire debate and seek to clarify its disciplinary integrity and its interdisciplinary relationships in a theoretical way, the second circumstance requires that social science should seek to develop interdisciplinary work and relationships in key areas, such as in relation to the questions concerning the nature and form of regimes for the protection of intellectual property and the evaluation of genetic services or interventions. 


\section{(iii) The Meaning of Genomics and Post-Genomic Science for Human Identity}

Marc Quinn's portrait in the National Portrait Gallery of Sir John Sulston, Nobel laureate in Physiology or Medicine, posed starkly the issues of genetic or genomic essentialism. Quinn's portrait is simply the analysis of Sulston's DNA on jelly in a plate. Is John Sulston, so this portrait seemed to ask, this particular DNA sequence? Whilst in the rest of the Gallery we would scrutinise the faces of the subjects in an endeavour to fathom or understand the person depicted (something we might attempt even in the event of our knowing nothing else of a person's life or circumstances), this portrait seems to pose the question as to whether the person who is mysteriously and problematically present to us in his or her face, is properly present to us in his or her genome, once we have learnt to read it.

Of course the move beyond genomics to proteomics and metabolomics is already, in effect, a repudiation of this genomic essentialism-we need to understand much more than the functions and interactions of genetic material, even in the totality of the genome, if we are to understand the biology of organisms. However that may be, it is nonetheless the case that genomics has served to reinforce the view which predates it, namely that genetic information is peculiarly personal or fundamental information and somehow goes to the heart of who we are. As well as affecting understanding of, and attitudes to, individual responsibility, genomic science and technology (in the shape of DNA profiling, for example) is increasingly being used to create, inform and shape categories of identity (such as race, ethnicity, sexuality, criminality and health status). Social science's concern to contribute to the policy debate must be expressed, then, not only in its contribution to the discussion of questions of very immediate policy significance, but also in continuing to maintain a broader perspective of reflection on the meaning of genomics and post-genomic science for human identity and self-understanding.

\footnotetext{
${ }^{1}$ I. Diamond \& D. Woodgate. Genomics research in the UK - the social science agenda. New Genetics \& Society 2005; 24(2): 239-252.

${ }^{2}$ The Innovative Health Technologies programme was also sponsored by the Medical Research Council. The Programme Director of the Innovative Health Technologies Programme was Andrew Webster, SATSU, University of York. The Programme Director for the Science in Society Programme is Steve Rayner, James Martin Centre for Science and Civilization, University of Oxford.

${ }^{3}$ The European Commission has funded research through, for example, the $6{ }^{\text {th }}$ Framework Funding Programme (FP6). One of the thematic priorities of FP6 is 'Life Sciences, Genomics and Biotechnology for Health'. Here, although many of the funding is for scientific projects, FP6 leaves significant scope for contribution from ethicists and social scientists: 'Ethical and regulatory issues should be taken into account, and experts, patients, and the public involved and consulted as appropriate, in an effort to promote socially responsible choices, public acceptance and an efficient exploitation of the new technologies being developed.' (See: http://www.cordis.lu/lifescihealth/applications/home.htm).

${ }^{4}$ The projects listed in Table 1 were reviewed during February, March and April, 2005. In order to reflect the current research landscape, only recent projects - those active or completed during or after 2002 - were selected. The list of projects in Table 1 is neither fully comprehensive nor ordered according to any scale or prioritisation. Rather, the projects are a selection broadly representative of the current research landscape in the UK. Projects were selected from the websites of a wide range of centres and funding bodies' websites, many of which are described in Part I. Although every attempt was made to ensure that the table is accurate, projects may have evolved such that they are currently misrepresented. Apologies to any relevant projects that may have been omitted.
} 
5 Thus the text in Part III is organized according to themes but Table 1 is not-the authors would
not wish to suggest that research projects could only be classified according to the themes we have
prescribed them. The choice of, or basis for, any classification scheme is never unproblematic and
most always contingent, and this is also the case for the classification of a diverse range of research
projects according to a few cross-cutting themes.
${ }^{6} \mathrm{M}$. McLuhan \& Q. Fiore. 1967. The Medium is the Massage. New York. Bantam.
${ }^{7}$ Z. Bauman. 1998. Globalization: The Human Consequences. Cambridge. Polity Press: 58-59; cited in M. Jackson. Biotechnology and the Critique of Globalisation. Ethnos 2002; 67(2): 141-154.

${ }^{8}$ M. Jackson. Biotechnology and the Critique of Globalisation. Ethnos 2002; 67(2): 141-154, 152.

${ }^{9}$ Whether or not the impacts of globalisation on people's health in developing countries have been negative, positive or neutral is debatable. For two differing perspectives, see, for example D. Dollar. Is globalization good for your health? Bulletin of the World Health Organization 2001; 79(9): 827-833; and G.A. Cornia. Globalization and health: results and options. Bulletin of the World Health Organization 2001; 79(9): 834-841.

${ }^{10}$ N. Clark, K. Stokes \& J. Mugabe. Biotechnology and development: threats and promises for the $21 \mathrm{st}$ century. Futures 2002; 34: 785-806.

${ }^{11}$ Capacity in this sense refers not only to scientists but also to 'entrepreneurial capabilities, supportive institutions and associated networks needed to translate raw scientific data into economic production':

Clark et al., op. cit. note 10, p. 791.

12 See projects $2-8$, Table 1.

${ }^{13}$ N. Clark \& J. Smith. Biotechnology and development: threats and promises for the 21 st century. Futures 2001; 34: 785-806.

${ }^{14}$ See especially Table 1, projects 3 ('Indigenous Peoples', Cesagen), 4 ('Genomics and biotechnology partnerships in Africa', Innogen), 5 ('Genomics and biotechnology partnerships in less developed countries', Innogen), 6 ('Institutional impacts of north-south partnerships in agricultural biotechnology', Innogen), \& 9 ('The impact of advanced genomics-based tools for agronomy, plant breeding and food production on local agricultural practices', Egenis).

${ }^{15}$ Table 1, Project 3 ('Indigenous Peoples', Cesagen).

${ }^{16}$ Table 1, Project 8 ('Bioethical implications of globalisation processes (BIG)', Cesagen).

${ }^{17}$ Table 1, Project 2 ('Action research to develop IEC materials that support informed consent processes for research in developing countries', Wellcome Trust/ KEMRI).

${ }^{18}$ Nuffield Council on Bioethics. 2002. The Ethics of Research Related to Healthcare in Developing Countries. London. Nuffield Council on Bioethics. The Wellcome Trust cites the Nuffield Council on Bioethics report as well as others in its position statement on research in people living in developing countries (At http://www.wellcome.ac.uk/doc_wtd015295.html).

${ }^{19}$ Whether or not, or the extent to which, states have been or are being hollowed out is the matter of some debate. For more general discussions on governance, see, for example: R.A.W. Rhodes. The Hollowing Out of the State: The Changing Nature of the Public Service in Britain. Political Quarterly 1994; 65(2): 138-151; R. Rhodes. 1997. Understanding Governance: Policy Networks, Governance, Reflexivity and Accountability. Buckingham. Open University Press; J. Kooiman (ed.). 1993. Modern Governance: New government-society interactions. London. Sage.

${ }^{20}$ J. Newman. 2001. Modernising Governance. London. Sage: 15.

${ }^{21}$ J. Kooiman (ed.). 1993. Modern Governance: New government-society interactions. London. Sage: 3.

${ }^{22}$ R. Rhodes. 1997. Understanding Governance: Policy Networks, Governance, Reflexivity and Accountability. Buckingham. Open University Press: 46

${ }^{23}$ As a hypothetical example, the interests of industry and scientific communities could become aligned with patient advocacy groups in the case of stem cell research, whilst people within such patient advocacy groups might mobilize against industry on the commercialisation of GM crops.

${ }^{24}$ H. Gottweiss. The governance of genomics. Critical Public Health 2002; 12(3): 207-220, 208.

${ }^{25}$ Ibid.

${ }^{26}$ R. Bunton \& A. Petersen. Genetics, ethics and governance. Critical Public Health 2002; 12(2): $95-$ $102,97$.

${ }^{27}$ M. Jones \& B. Salter. The governance of human genetics: policy discourse and constructions of public trust. New Genetics \& Society 2003; 22(1): 21-41, 22.

${ }^{28}$ B. Salter \& M. Jones. Regulating human genetics: the changing politics of biotechnology governance in the European Union. Health, Risk \& Society 2002; 4(3): 325-340, 326.

${ }^{29}$ Ibid. 


\footnotetext{
${ }^{30}$ Numerous authors have discussed this. See, for example: N. Brown \& M. Michael. From authority to authenticity: the changing governance of biotechnology. Health, Risk \& Society 2002; 6(3): 259-272;

A. Irwin. Constructing the scientific citizen: science and democracy in the biosciences. Public Understanding of Science 2001; 10(1): 1-18; B. Wynne. The Public Understanding of Science. In: Handbook of Science and Technology Studies. S. Jasanoff et al. (eds.). 1995. London. Sage.

31 e.g. Wynne, op. cit. note 30.

${ }^{32}$ B. Wynne. Seasick on the Third Wave? Subverting the Hegemony of Propositionalism. Social Studies of Science 2003; 33(3): 401-417, 412.

33 e.g. Bunton \& Petersen, op. cit. note 26; Jones \& Salter, op. cit. note 27.

${ }^{34}$ Prime Minister's Strategy Unit. 2003. Fieldwork: Weighing up the costs and benefits of GM crops.
} At http://www.number-10.gov.uk/su/gm/index.htm; quoted in R. Levitt. 2003. GM Crops and Foods: Evidence, policy and practice in the UK: a case study. London. Sage: 8.

${ }^{35}$ S. Campbell \& E. Townsend. Flaws undermine results of UK biotech debate. Nature 2003; 425: 559.

${ }^{36}$ W. Poortinga \& N. Pidgeon. Trust in Risk Regulation: Cause or Consequence of the Acceptability of GM Food? Risk Analysis 2005; 25(2): 199-209.

${ }^{37}$ House of Commons Select Committee on Environment, Food and Rural Affairs. 2003 Conduct of the GM public debate: eighteenth report. London. Stationery Office: Para 41; quoted in Levitt, op. cit. note 34, p. 20.

${ }^{38}$ E.g. Brown \& Michael, op. cit. note 30; Bunton \& Petersen, op. cit. note 26; Irwin, op cit. note 30; Wynne, op. cit. note 30 .

39 Jones \& Salter, op. cit. note 40, p. 27.

40 e.g. Bunton \& Petersen, op. cit. note 26.

${ }^{41}$ The tensions related to the application of genomics for individual versus collective health benefit have been explored by, for example: E. Willis. Public health and the 'new' genetics: balancing individual and collective outcomes. Critical Public Health 2002; 12(2): 139-151.

${ }^{42}$ Particularly, projects 10, 30-49 \& 71-98 in Table 1.

${ }^{43}$ See, for example, Table1: Project 10 ('The global politics of human embryonic stem cell regulation', University of East Anglia), 30 ('Accountability and the governance of expertise: anticipating genetic bioweapons' University of Exeter), 33 ('Representations of complexity in policy networks', IGBiS), 43 ('Quality assured science: the role of standards in stabilising stem cell research', SATSU) \& 111 ('Medical device governance: regulation of tissue engineering in the UK and EU', Cardiff University). ${ }^{44}$ See, for example, table 1: Project 30 ('Accountability and the governance of expertise: anticipating genetic bioweapons' University of Exeter), 33 ('Representations of complexity in policy networks', IGBiS) \& 46 ('Trading up environmental standards? Trans-atlantic governance of GM Crops', The Open University).

${ }^{45}$ See Table 1: Projects 39 ('Reforming the governance of human genetics: The politics of public trust', University of East Anglia), 45 ('PARADYS: Participation and the dynamics of social positioning ', University of Lancaster / IEPPP), 74 ('The emerging politics of new genetic technologies', Cesagen), 81 ('Deliberative Mapping', SPRU), 98 ('The social dynamics of public engagement in stem cell research', Innogen).

${ }^{46}$ See Table 1, Project 81 ('Deliberative Mapping', SPRU).

${ }^{47}$ e.g. Table 1, Projects 52 ('Transformations in genetic subjecthood', SATSU / University of Edinburgh), 75 ('Public perceptions of risk, science and governance', University of East Anglia), 80 ('Childhood vaccination: science and public engagement in international perspective', University of Sussex).

${ }^{48}$ e.g. Table 1, Project 98 ('The social dynamics of public engagement in stem cell research', Innogen).

49 Table 1, Project 52 ('Transformations in genetic subjecthood', SATSU / University of Edinburgh).

${ }^{50}$ Table 1, Projects 79 ('Factors affecting preimplantation genetic diagnosis (PGD): Patient's attitudes toward donation of embryos for stem cell research', Cesagen) \& 93 ('A comparative study of embryo donors' views on embryo experimentation for preimplantation genetic diagnosis and stem cell therapy', PEALS).

${ }^{51}$ Table 1, Project 93 ('A comparative study of embryo donors' views on embryo experimentation for preimplantation genetic diagnosis and stem cell therapy', PEALS).

${ }_{52}$ Table 1, Projects 52 ('Transformations in genetic subjecthood', SATSU/University of Edinburgh), 72 ('Definitions of genetic knowledge \& pre-implantation genetic diagnosis: an ethnographic study', Cesagen), \& 105 ('Genetic screening for susceptibility to disease: the case of haemochromatosis', Cesagen). 
${ }^{53}$ Table 1, Project 72 ('Definitions of genetic knowledge \& pre-implantation genetic diagnosis: an ethnographic study', Cesagen).

${ }^{54}$ Table 1, Project 78 ('Variability in response to warfarin: a prospective analysis of pharmacogenetic and environmental factors', University of Liverpool / SATSU).

${ }^{55}$ Table 1, Project 29 ('The institutionalisation of ethics in science policy: practices and impact', Cesagen).

${ }^{56}$ See Projects $15-29$, Table 1.

${ }^{57}$ For example, Table 1, Projects 15 ('Social and ethnic differences in attitudes and consent to prenatal testing', University of Leeds) \& 16 ('Informed consent and genetic data', University of Cambridge).

The latter is also asking more broadly about the sort of information required for consent to be legitimate.

${ }^{58}$ Table 1, Project 20 ('Ethical protection in epidemiological genetic research: participants' perspectives', University of Bristol).

${ }^{59}$ For example, Table 1, Project 25 ('Informed consent in Sri Lanka', King's College, University of London).

${ }^{60}$ Table 1, Project 28 ('Ordinary ethics: moral evaluation of the new genetics by non-professionals', PEALS).

${ }^{61}$ Jones \& Salter, op. cit. note 27, p. 22.

${ }^{62} \mathrm{P}$. Martin and R. Frost. Regulating the commercial development of genetic testing in the UK: problems, possibilities and policy. Critical Social Policy 2003; 23(2): 186-207, 206.

${ }^{63}$ A. Giddens. 1990. The Consequences of Modernity. Cambridge, UK. Polity: 111.

${ }^{64}$ N. Brown \& Michael. Risky Creatures: Institutional Species Boundary Change in Biotechnology Regulation. Health, Risk and Society 2004; 6(3): 207-222.

${ }^{65}$ Brown \& Michael, op. cit. note 30, p. 260.

${ }^{66}$ e.g. S. Jasanoff. 1990. The Fifth Branch: Science Advisers as Policymakers. Cambridge, MA. Harvard University Press.

${ }^{67}$ e.g. Ibid.; Irwin, op. cit. note 30.

${ }^{68}$ Jasanoff op. cit. note 66, p. 178.

${ }^{69}$ e.g. W. Bijker, T. Hughes \& T. Pinch (eds.). 1987. The Social Construction of Technological Systems. Cambridge, MA. MIT Press; and D. MacKenzie \& J. Wajcman. 1999. The Social Shaping of Technology, 2nd Edition. Buckingham. Open University Press.

${ }^{70}$ This notion has also been challenged. See, for example: P. Nightingale \& P. Martin. The Myth of the Biotech Revolution. Trends in Biotechnology 2004; 22(11): 564-569.

${ }^{71}$ At http://www.bioindustry.org/bigtreport/vision.html

${ }^{72}$ Department of Trade and Industry. 1999. Genome Valley: The Economic and Strategic Importance of Biotechnology in the UK. London. Department of Trade and Industry: 37.

${ }^{73}$ Ibid., p. 34

${ }^{74}$ E.g. Nightingale \& Martin, op. cit. note 70.

75 e.g. J. Tait \& J. Mittra. 2004. Complexity and Innovation in the Pharmaceutical Industry. At http://www.innogen.ac.uk.

${ }^{76}$ World Health Organization. 2002. Genomics and World Health. Geneva. World Health Organization: $127-133$

${ }^{77}$ Ibid., pp. 132-133

${ }^{78}$ For an extended discussion on this topic, see S. Jasanoff. 2005. Designs on Nature: Science and Democracy in Europe and the United States. Princeton, N.J. Princeton University Press.

${ }^{79}$ For example, Table 1, project 46 ('Trading-up environmental standards? Transatlantic governance of GM crops', Innogen).

${ }^{80}$ Table 1, Project 100 ('Xenotransplantation: risk identities and the human / non-human interface', Goldsmiths College, University of London / SATSU) \& 109 ('Forgotten fetuses - a sociocultural analysis of the use of fetal stem cells', University of the West of England, Bristol).

${ }^{81}$ Table 1, project 43 ('Quality assured science: the role of standards in stabilising stem cell research', SATSU).

${ }^{82}$ e.g. Table 1, project 110 ('Haematopoietic stem cells: the dynamics of expectations in innovation', IGBiS / SATSU).

${ }^{83}$ Table 1, Project 108 ('Mapping stem cell innovation in action', King's College, University of London). See also Table 1, Project 107 ('The ethical and public policy implications of the new genetics and transgenics in the carcinogenic risk assessment of pharmaceuticals', University of Sussex).

${ }^{84}$ Table 1, Project 67 ('Pharmacogenomics, diagnostic tests and clinician acceptance', SATSU). 


\footnotetext{
${ }^{85}$ See Table 1, Projects 68 ('The clinical and commercial development of pharmacogenetics', IGBiS / SATSU) \& 102 ('The regulation of small biotech start-up companies in Scotland and Norway', IGBIs). ${ }^{86}$ e.g. Table 1, Projects 60 ('The impact of genomics on innovation in the pharmaceutical industry', IGBiS / SPRU) \& 62 ('Transcending the genome: the paradigm shift to proteomics', Cesagen). ${ }^{87}$ e.g. Table 1,Projects 59 ('The public and private organisation of genetic information', Innogen ${ }^{88}$ See Table 1, Projects 57 ('The evolution of biomedical knowledge: interactive innovation in the UK and US', University of Warwick) \& 12 ('Corporate responses to macroeconomic changes and shocks', University of Cambridge).

89 J.H. Evans' recent work, Playing God? (J.H. Evans. 2002. Playing God? Human Genetic Engineering and the Rationalization of Public Bioethical Debate. Chicago, University of Chicago Press), addresses the importance of this point. According to Evans, the very structuring of the debate about what he terms 'human genetic engineering' (HGE) has precluded the possibility of 'thick' as opposed to 'thin' debate about public policy. This contrast he explains by borrowing Weber's distinction (in Economy and Society) between formal and substantive rationality. Action is substantively rational if it applies criteria of ultimate ends or values to decision-making; action is formally rational if it simply calculated to be the way to achieve predetermined or assumed ends. Debate about HGE is, he contends, increasingly of the formally rational kind and thus 'thin'.
} 